\title{
O Branco Arroz Negro: A História Oculta de um Alimento de Todo o Dia
}

Rogério Ribeiro de Oliveira 1

\section{Book Review:}

Judith A. Carney, Arroz Negro: As Origens Africanas do Cultivo Do Arroz Nas Américas (Bissau: Instituto da Biodiversidade e das Áreas Protegidas, 2017).

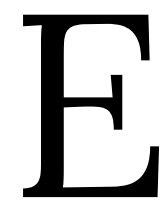

xistem dois aspectos biológicos muito peculiares da trajetória humana sobre o planeta: a domesticação de espécies e a introdução plantas de um lugar para outro. A seleção de espécies que possam ser diretamente ingeridas pelos humanos é uma consequência natural de sua vivência. A domesticação foi uma etapa fundamental da história humana, que permitiu sua expansão por todo o globo. Foi uma história reescrita e que moldou definitivamente o planeta ao ser humano. As paisagens se modificaram de forma radical ao se tornarem campos agrícolas. A diversidade original dos biomas foi reduzida somente a espécies vegetais de uso direto e cultivadas pelo homem. Esse espaço para as novas espécies foi obtido à custa de severas transformações dos ecossistemas e paisagens. Há 150 anos, a humanidade se alimentava com o produto de 3 mil espécies vegetais que, em 90\% dos países, eram 
consumidas localmente. Atualmente quinze espécies respondem por 90\% dos alimentos vegetais e, destes, apenas quatro culturas - trigo, milho, arroz e soja respondem por $70 \%$ da produção e do consumo mundiais ${ }^{2}$.

No entanto, o processo de domesticação e expansão de espécies não foi nem de longe de uma história linear, uma simples incorporação de espécies recémdomesticadas à dieta humana. As trajetórias, geográficas, políticas e/ou sociais assumiram contornos de grande complexidade nos lugares onde chegaram estas "novas" espécies. É o que aprendemos na obra Arroz negro: as origens africanas do cultivo do arroz nas Américas, de Judith Carney ${ }^{3}$. A par de todas as mudanças ecológicas que estas introduções permitiram, como o aumento da população e a sedentarização, novas relações de poder se estabeleceram entre povos que chegavam e os que já se encontravam nas terras a serem colonizadas. Novos cultivares passaram a representar poder sobre os povos colonizados e a introdução de novos hábitos alimentares tornaram-se uma condição sine qua non para os mais diversos projetos expansionistas. Novos alimentos, novas formas de poder. Os novos cultivares levaram à emergência de paradigmas socioeconômicos, mudando relações globais. Assim, como o cultivo do arroz chegou ao atual patamar de ser um dos principais alimentos da raça humana? Quais foram os caminhos que este cereal seguiu, para passar de uma simples gramínea a uma das bases da alimentação humana? Como foi o seu processo de domesticação e de expansão pelo globo? Muitas dessas respostas estão em o Arroz negro. A motivação para escrever a obra, segundo a sua autora, partiu de duas oportunidades de campo: uma pesquisa feita no seu doutoramento na Gâmbia (África Ocidental) e outra, no México, quando se integrou ao Centro de Investigação do Milho e do Trigo. O que mais chamou a sua atenção foi uma aldeia que conheceu em suas viagens, com população mista de mexicanos e africanos. Nela, Carney conseguiu informações de que os africanos trouxeram conhecimentos cruciais para a instalação e desenvolvimento da rizicultura na Carolina, Estados Unidos. Foi o mote para o desenvolvimento da pesquisa que redundou nesta obra.

\footnotetext{
2 Amélio Dall'Agnol, "Grandes Produtores e Consumidores de Alimentos," Agrolink, 2018, https://www.agrolink.com.br/colunistas/grandesprodutores-e-consumidores-de-alimentos_409025.html.

3 Judith A. Carney, Arroz Negro: As Origens Africanas Do Cultivo Do Arroz Nas Américas (Bissau: Instituto da Biodiversidade e das Áreas Protegidas, 2017).
} 
A perspectiva utilizada por Carney é interdisciplinar, intercultural e interregional. Por esse caminho amplo, a obra ajuda a resgatar uma contribuição extremamente significativa para a história da agricultura nas Américas. Essa interdisciplinaridade traz ao leitor um amplo espectro de enfoques que vão da genética de grãos à cultura e a estudos de gênero. Essa obra, sem dúvida, oferece ao leitor a medida da complexidade da história de um alimento tão importante na nossa mesa.

Apesar de sua origem asiática, a obra de Carney deixa clara a importância do arroz africano e das competências culturais africanas na instalação e desenvolvimento da rizicultura nas Américas. Este é o ponto central de sua obra. Ela explica de forma cabal as diferenças e origens diversas das duas principais espécies de arroz, Oriza sativa e O. glaberrima. No entanto, fica pouco clara a evolução histórica das formas de seleção e de cultivo do arroz de sequeiro, intensamente cultivado nas Américas. O foco maior do livro é o arroz plantado em áreas alagadas.

A livro ajuda a derrubar uma noção superada de que os escravizados trouxeram poucas contribuições e competências para o Novo Mundo. De fato, na qualidade de emigrantes forçados, a bagagem material de um escravizado devia ser mínima ou inexistente. Sementes de arroz africano, no entanto, acompanharam essa emigração, trazidas a bordo para alimentação ao longo da travessia. O arroz trazido dos portos africanos para a alimentação em viagem teve uma parte utilizada como semente. Os escravos passaram a cultivá-lo sempre que as condições sociais ou ambientais eram favoráveis. No entanto, particularmente para o seu cultivo, não bastavam as sementes. Segundo Carney, o arroz constitui na verdade um sistema de conhecimentos. Saber cultivá-lo tem a mesma importância de se dispor das sementes. Tudo se torna complicado, particularmente a partir de grande parte da cultura do cereal se dar em condições de alagadas. O manejo da água e o calendário agrícola integram um complexo sistema de conhecimentos.

Subjacente a toda a narrativa está o fato apontado pela autora de que os cereais africanos foram considerados alimentos inferiores e de má qualidade. Uma visão claramente eurocêntrica colocava os agricultores africanos em um nível menos evoluído dentro da hierarquia da agricultura, civilização e progresso, o que evidencia 
preconceitos persistentes em relação a tudo que vinha da África. Carney destaca o fato de que historiadores ambientais devam ter o foco das culturas de exportação produzidas por escravos para os alimentos que os mesmos plantavam para seu sustento. E que em pouco tempo aumentaram em muito a sua importância na colônia, redirecionando tanto economia e paisagem. $\mathrm{E}$ isso passou de uma escala de pequenos quintais à incorporação à dieta do país.

Outro ponto é a relatividade das lógicas de produção. Enquanto que na África Ocidental a lógica é a subsistência em um contexto ambiental complexo e que nivela a necessidade de mão de obra durante o calendário agrícola (cheias, secas, marés, etc.), na Carolina do Sul o uso da terra foi concebido para a obtenção do lucro. Essa diferença marcou toda a paisagem das Américas. Ao cotejar técnicas agronômicas com aspectos culturais e sociais, Carney traz à reflexão a importância do trabalho das mulheres e a questão da identidade cultural de grande parte da África Ocidental, ausentes ainda hoje nas realidades sociais e ecológicas nos países colonizados.

\section{REFERENCIAS}

Carney, Judith A. Arroz Negro: As Origens Africanas Do Cultivo Do Arroz Nas Américas. Bissau: Instituto da Biodiversidade e das Áreas Protegidas, 2017.

Dall'Agnol, Amélio. "Grandes Produtores e Consumidores de Alimentos." Agrolink, 2018. https://www.agrolink.com.br/colunistas/grandes-produtores-econsumidores-de-alimentos_409025.html. 